\title{
Reforms on Employment And Unemployment In Uzbekistan: Functional Approach
}

\author{
Akbarova Laylo Upashevna - Senior Lecturer, Department of Economics, Tashkent State Transport University \\ Shonazarova Nilufar Baratovna - Assistant Department of Economics, Tashkent State Transport University \\ Khaydarov Ismatulla Asadullaevich - Assistant Department of Economics, Tashkent State Transport University
}

\begin{abstract}
The article provides information on the reforms implemented in Uzbekistan in recent years on employment and unemployment and their results. Scientific and legal approaches to the concept of employment are presented. In addition, the article examines the changes in the world economy and labor market due to the global catastrophe called the COVID-19 pandemic, provides measures in this regard and statistical analysis of employment in Uzbekistan. In the process of consistent development of social and economic relations, the issues of employment and further improving the living standards of the population, increasing production in various sectors in Uzbekistan, drastically reducing the number of unemployed through further development of small business and private entrepreneurship, home-based work, family business tasks related to the ongoing employment policy and aspects related to the social mechanism of increasing employment were studied.
\end{abstract}

\section{Keywords:}

employment, unemployment, mechanism, employment policy, legal framework, scientific and economic characteristics, labor market, international experience, protection against unemployment.

Article Received: 18 October 2020, Revised: 3 November 2020, Accepted: 24 December 2020

\section{INTRODUCTION}

The proclamation of the Republic of Uzbekistan as an independent state has led to radical changes in the socio-economic, political and cultural spheres of our society. These changes directly necessitated the need to increase employment of the population of our country and the formation of its social mechanisms. While the scientific study of employment serves to improve the teachings of sociology, economics, psychology, law, it also allows to determine the strategy of targeted use of available resources to ensure national development [1].

\section{Materials and Methods}

The concept of employment etymologically means the employment of the able-bodied population and participation in economic activities. This kind of interpretation, in turn, is sufficient to conclude directly that employment is the basis for providing the population with a way of life and engaging them in material and spiritual creative activities. In our opinion, employment includes job selection for a specific profession, vocational training (including vocational training), retraining and advanced training, financial assistance to those who have lost their jobs, work in new specialties based on the requirements of the labor market. requires maintenance. It satisfies the needs of labor and its various spheres by providing an important aspect of human maturity, namely the social aspect. Article 4 of the Law of the Republic of Uzbekistan "On Employment" defines the concept of employment: "Employment is an activity of citizens that is not prohibited by law, related to the satisfaction of their personal and social needs, bringing them wages (income)". "Citizens have the exclusive right to use their abilities for production and creative work and to carry out any activity not prohibited by law, including the performance of paid work" [2].

The National Encyclopedia of Uzbekistan states: "Employment - of the able-bodied population in socially useful work; activities related to the satisfaction of personal and social needs of citizens and which do not contradict the law and provide income"[3]. 
Guarantees of employment in the country, the realization of the right to work in Articles 37, 38, 39 of the Constitution of the Republic of Uzbekistan [4], as well as the Law of the Republic of Uzbekistan "On Employment" as amended and supplemented on October 20, 2020 Law No. LRU642. reflected. Article 37 of the Constitution of the Republic of Uzbekistan states: "Everyone has the right to work, to free choice of employment, to just and favorable conditions of work and to protection against unemployment in accordance with the law. It is stated that forced labor is prohibited, except for the order of serving a sentence imposed by a court or in other cases provided by law" [5], and that the state protects the personal freedom of citizens in employment.

Employment policy is directly related to demographic processes in the region. Because Uzbekistan is one of the youngest countries in the world and the average age of the population is 26 years. This is a sign that the country has a huge workforce. Today, the population of Uzbekistan is about 34 million people, about $50 \%$ of whom live in rural areas, while $57 \%$ of the country's total labor force is in rural areas, and their number exceeds 7.2 million people [6]. This situation will allow the labor force in the XXI century to form a majority of people with high labor activity and professional training.

In this regard, in the Address of President Sh. Mirziyoev to the Oliy Majlis in December 29, 2020, “...non-governmental non-profit organizations are widely involved in identifying existing problems, their in-depth analysis, development of proposals for solutions, ensuring public control over their implementation" He noted "that 60 billion soums will be allocated from the budget next year for the organization of this work, and outlined the priorities for employment" [7]. He also noted that in 2021, "500 billion sums will be allocated from the Employment Promotion and Public Works Funds to provide employment for the needy". [8]

\section{RESULT AND DISCUSSION}

Historical experience shows that $[9,10,11]$, trying to solve the problems of society without taking into account the personality and needs of the person is doomed to failure. Therefore, it is no coincidence that in the past, when scientists considered employment problems, they focused mainly on its economic aspects, but in recent years, more and more attention has been paid to the sociocultural and psychological aspects of employment [12]. Because the formation and expansion of the service sector in society, the emergence of new specialties requires a comprehensive approach to employment. According to O.V.Zayats, employment has its own components, which are:

1. social employment;

2. public - private employment;

3. regional employment;

4. sectoral employment;

5. occupational age and gender employment;

6. national employment;

7. family employment [13] etc.

Socio-demographic issues of employment have always been relevant as a scientificsociological, scientific-economic topic $[14,15,16$, 17, 18, 19]. The historical, gender, culturalpsychological and economic-legal aspects of this topic have not lost their relevance to this day. Statistics and the results of sociological research show that the problem of employment is protected not only in our republic, but also in other countries by the Constitution [20, 21] and other laws.

Employment has a historical and regional, periodic and economic content. It should be noted that since the second half of the twentieth century, domestic and foreign labor markets have been formed [22], which can be divided into groups, taking into account their global content. If we take into account that the labor market also serves to gather information related to the process of acquiring specialized professional knowledge, it can be observed that today different models of labor markets have been formed [23]. Theoretically, they can be expressed as a model of the USA labor market, a model of the Japanese labor market, a model of the Swedish labor market, 
a model of the labor market of the Russian Federation [24].

The social and psychological aspect of the USA labor market model is that it is characterized by the activity of labor market actors. The state, on the other hand, supports competition. With a special focus on individual success in work, high wages are being cultured by the state, science and education, and the media. As a result, the American citizen is "busy" earning income, increasing it, buying shares and raising more money. Domestic and foreign labor markets have been formed in the United States. Their activities, on the other hand, differ fundamentally in organizational and methodological terms. Entrepreneurship and employee activities are financially encouraged. Unemployment insurance is regulated by state federal law. A unique, socio-cultural aspect of the Japanese labor market is that there is a "lifelong recruitment system" by enterprises to attract workers to work, that is, to engage in labor activity [26]. The length of service and age of employees are taken into account when paying wages. However, in recent days, special attention has been paid to the qualifications of workers. During the period 1974-1975, after the crisis in Japan, there were changes in the "lifelong employment system", the protection of hired workers decreased, and the share of permanent jobs decreased. Services (third sector) developed and an external labor market emerged.

The Swedish labor market model is characterized by active employment policy. This is characterized by the fact that the labor market has a state market mechanism, dominated by state regulation. For this purpose, according to the data of $1993-1994,70 \%$ of employment or $3.5 \%$ of GDP is spent. Unemployment benefits range from $2.7 \%$ of GDP [27].

The Russian labor market is characterized by the active participation of employers and workers. According to OV Zayats, employment in the Russian Federation has its own structure. At the same time, education and professional specialization are distinguished by gender aspects. It is noted that "In general, 50\% of those employed in the economy have secondary vocational and higher education, and the proportion of women is much higher than men (59.2 and 43.7\%)" [28].

According to sources, the share of the state in the economy of the Russian Federation to date has served as a basis for the emergence of an external labor market, as all types of education are high [29].

Uzbekistan is one of the fastest growing countries in the world. The population of the republic is growing annually by an average of 550600 thousand people, and the working age population is growing by 320-350 thousand people [30]. According to professors K.Abdurahmanov and B.Umurzakov, "the demographic situation in our country is healthy, the population and the economy are growing in proportion. If the birth rate remains at the current level until 2030, 710-720 thousand young men and women will enter the labor market every year. In turn, 230-240 thousand people will reach retirement age. In this sense, it is important to take measures now to attract young people to work".[31]

In September 2020, the Republican Scientific Center for Employment and Labor Protection of the Ministry of Employment and Labor Relations conducted a public survey in 108 cities and districts of the country. The study covered 490 self-governing bodies, 4,900 households and 26,000 citizens [32].

The number of labor resources in JanuarySeptember 2020 amounted to 19 million 121.3 thousand people, an increase over the same period in 2019 by $100.7 \%$ or 135.5 thousand people.

The number of people employed in the economy amounted to 13 million 205.2 thousand people, an increase over the first half of the year by $3.7 \%$ (468.5 thousand people).

In January-September, the number of people employed in the official sector amounted to 5 million 673.8 thousand people, an increase of $1.7 \%$ or 92.6 thousand people compared to January-June this year.

The number of people employed in the informal sector amounted to 5 million 618.8 thousand people, an increase of $9.9 \%$ or 504.2 
thousand people compared to January-June this year. This was mainly due to the return of labor migrants leaving the country to work in the domestic labor market and the increase in the number of people engaged in seasonal work in agriculture.

The number of people leaving the country for work amounted to 1 million 912.6 thousand people, which is 128.3 thousand people or $6.3 \%$ less than in January-June.

According to the survey, the total number of people in need of work was 1 million 642.5 thousand people. The unemployment rate among the economically active population was 11.1 percent. The unemployment rate among those aged 16-30 was 17.1 percent, and the unemployment rate among women was 14.7 percent.

In January-September, the economically inactive population of Uzbekistan amounted to 4 million 273.6 thousand people, a decrease of $3 \%$ or 130.3 thousand people compared to the first half of the year [33].

During the first 9 months of the year, 910,201 citizens who applied to the district and city employment centers were served.

Of the applicants, 243,946 were employed, 500,449 were involved in public works, 25,384 were unemployed, 45,036 were granted unemployment benefits, and 38,002 were provided with employment counseling.

In addition, 30,827 families were employed on private farms, 19,174 people were employed in agricultural, sewing and handicraft cooperatives, and 7,383 people were involved in entrepreneurship due to subsidies from the Employment Promotion Fund.

In the second quarter of 2020, the unemployment rate in Uzbekistan was up to $15 \%$, and in January-June - $13.2 \%$, in January-September - $11.1 \%$, compared to the first half of the year $2.1 \%$ percent decreased [34]. This is the result of reforms in the field of employment and unemployment in our country.

This situation, in turn, will require an increase in employment, which will require the expansion of production, continuous work to create new jobs and improve legislation. Another factor contributing to the destabilization of society is the lack of employment, ie the lack of employment as a social factor. Other factors include:

production stagnation;

breaking the link between science and industry;

immaturity of the legal framework;

the presence of hidden unemployment;

uncontrolled migration;

lack of information on vacancies.

This, in turn, requires the formation and protection of the national labor market. Otherwise, there may be problems of cultural, pedagogical, psychological, demographic, medical, legal content $[35,36]$ associated with the decline in living standards, increasing the number of unemployed in the country. For example, the formal job search or the informal job search situation can indicate that various forms of conflict arise as a result of the destabilization of the mental state of the unemployed.

\section{CONCLUSION}

1. It is necessary to improve the system of employment, to introduce acceptable forms of incentives for those who are engaged in entrepreneurial activities and create jobs;

2. It is expedient to conduct a scientific and sociological study of slang and jargons related to the employment process and to determine the degree of its connection with industry and production, other areas and the management of the labor process;

3. Based on the needs and supply of the labor market, it is necessary to improve the classification of professional specialties and establish social system relations such as "Production - Education - Production Professional Development - Professional Competence - Retraining - Production";

4. It is necessary to improve the functioning of social institutions dealing with labor and employment in a functional and institutional way, and to monitor the issues of labor satisfaction and labor efficiency. 


\section{REFERENCES}

[1] Shevchuk AL. Post-Fordist Concepts as a Research Program // Economic Sociology. 2002. Vol.3, No. 2. www.ecsoc.msses.ru

[2] Law of the Republic of Uzbekistan "On Employment" No. LRU-642. October 20, 2020, - https://lex.uz/docs/5055690

[3] National encyclopedia of Uzbekistan. Tashkent: "National Encyclopedia of Uzbekistan" State Scientific Publishing House, 2000. - B. 615.

[4] The Constitution of the Republic of Uzbekistan. - Tashkent, Uzbekistan. 2019. - P. 15.

[5] The Constitution of the Republic of Uzbekistan. - Tashkent, Uzbekistan. 2017. Pages 15-16.

[6] Prepared on the basis of information from the Statistics Committee of the Republic of Uzbekistan. - http: // www.lex.uz

[7] Address of the President of the Republic of Uzbekistan Shavkat Mirziyoev to the Oliy Majlis. December 29, 2020. http://uzlidep.uz/news-ofuzbekistan/7998

[8] Address of the President of the Republic of Uzbekistan Shavkat Mirziyoev to the Oliy Majlis. December 29, 2020. http://uzlidep.uz/news-ofuzbekistan/7998

[9] Problems of the development of society: ecology, economics, management: Collection of scientific papers. Edition II / Ulyanovsk State Technical University. Ulyanovsk, 2000 .- 112 p.

[10] Glushchenko EV, Zakharova EV, Tikhomirov Yu.V. Management theory: A training course. - M., 1997.

[11] Ansoff I. Strategic management / Per. from English - M., 1998.

[12] See more books in http: // www.ereading.club

[13] Zayats O.V. Employment of the population and its regulation. Vladivostok, Far Eastern University Publishing House, 2003. - P.10.
[14] Ananiev A.N. Socio-psychological consequences of unemployment http://www.mediatext.ru/docs/7005?page $=8$

[15] Borovik V.S., Ermakova E.E., Pokhvoshchev V.A. Employment. Rostov / on Don: "Phenix", 2001.

[16] Gertius Y. Unemployment is growing, its structure is changing // J. Man and Labor. - No. 7. - 2002. - S.62-65.

[17] Kashepov A. Labor market policy // J. Society and economy. - 2001. - No. 5.

[18] Svistunova E. Employment of disabled people: legal regulation in the regions // $\mathrm{J}$. Man and labor. - No. 2. - 2003. - P.37-41.

[19] Tovom Mario Self-employment of the population in Italy // J. Man and labor. No. 2. - 2003. - P.74-77.

[20] Constitutions of the world (Collection of constitutions of states of the world. V.3) Compilers and authors of the introduction, introductory articles U. Tadzhikhanov and A.Kh.Saidov. - T.: Academy of the Ministry of Internal Affairs of the Republic of Uzbekistan, 1998 .- 448 p.

[21] Constitutions of the world (Collection of constitutions of states of the world. V.5) Compilers and authors of the introduction, introductory articles U. Tadzhikhanov and A.Kh.Saidov. - T.: Academy of the Ministry of Internal Affairs of the Republic of Uzbekistan, 1998 . 463 p.

[22] Economics and sociology of labor: (social and labor relations). Tomsk: Publishing house of Tomsk State University, 2008. P. 41.

[23] Labor market. Textbook. Ed. Bulanova V.S. and Volgina N.A. - M.: "Exam", 2000., Genkin BM Labor efficiency and quality of life. - SPb.: GIEA, 1997.

[24] Filyev V.I. Organization, regulation and remuneration. The experience of foreign countries: Great Britain, Germany, Italy, USA, France, Japan, etc. - M., 1996.

[25] Economics and sociology of labor: (social and labor relations). - Tomsk: Publishing 
house of Tomsk State University, 2008 .P. 41.

[26] Volgin N.A. Japanese experience in solving economic and social - labor problems. - M .: Economics, 1998 .- 173 p.

[27] Economics and sociology of labor: (social and labor relations). - Tomsk: Publishing house of Tomsk State University, 2008. P. 42.

[28] Zayats OV Employment of the population and its regulation. - Vladivostok: Publishing House of the Far Eastern University, 2003. - P.14.

[29] Economics and sociology of labor: (social and labor relations). - Tomsk: Publishing house of Tomsk State University, 2008 .P. 42.

[30] http: // www.lex.uz

[31] Abdurakhmonov K., Umurzokov B. Employment and social activity.http://old.xs.uz/index.php/homepage/zha miyat/item/10649-a-oli-bandligi-vaizhtimoij-faollik

[32] https://www.gazeta.uz/uz/2020/11/14/ish sizlik

[33] https://www.gazeta.uz/uz/2020/11/14/ish sizlik

[34] https://www.gazeta.uz/uz/2020/11/14/ish sizlik

[35] Plyusnin Yu.M., Poshevnev G.S. Social psychology of the unemployed. Novosibirsk: CSA, 1997 .- 84 p.

[36] Titov V.N. Socio-psychological aspects of the functioning of the informal economy // J. Social sciences and modernity. 2002. No. 5. 